\title{
MEIO MODIFICADO DE CULTURA PARA CARACTERIZAÇÃO DE SALMONELLA LACTOSE POSITIVA
}

Falcão, D. P. - Meio modificado de cultura para caracterização de Salmonella lactose-positiva. Rev. Saúde públ., S. Paulo, 10:65-73, 1976.

Resumo: Foi desenvolvido um meio modificado de cultura para isolamento e caracterização de enterobactérias, visando especialmente salmonelas fermentadoras da lactose. No chamado "Meio modificado" as colônias das duas estirpes de Salmonella (lactose positivas e lactose negativas) apresentam a morfologia idêntica, o que não ocorre quando são empregados os meios rotineiros à base de lactose, para isolamento de enterobactérias. Esse meio é uma modificaçāo do meio de Hektoen Enteric Agar, do qual retirou-se lactose $e$ adicionou-se xilose e L-lisina. Foi verificado que há possibilidade de diferenciar-se os diversos grupos de enterobactérias, empregando um meio de cultura sem lactose e usando como sistema diferenciador xilose e L-lisina. O meio modificado foi também avaliado quantitativamente comparando o seu poder enriquecedor ou inibitório, ao dos meios de Heltoen Enteric Agar, Brilliant Green Agar $e$ SS Agar para diferentes grupos de enterobactérias.

Unitermos: Enterobactérias. Salmonella lactose-positiva. Meio de cultura.

\section{N T RODUÇ A}

No trabalho de rotina de caracterização de enterobactérias, o critério inicial para isolamento de Salmonella é a separação de colônias fermentadoras e não fermentadoras de lactose. Somente a partir de colônias lactose negativas realizam-se provas para identificação e caracterização de Salmonella.

Edwards e Ewing ${ }^{4}$ e Kauffmann ${ }^{9}$, ao definirem o gênero Salmonella afirmam que o mesmo é constituído por bactérias não fermentadoras da lactose.

Estirpes lactose positivas de Salmonella são consideradas raras. Em 1966, Ewing e Ball ${ }^{6}$ observaram que apenas $0,8 \%$ de amostras de Salmonella estudadas no Center for Disease Control (USA) eram lactose positivas, sendo que duas dessas amostras eram de sorotipo tennessee e a outra era typhimurium. Em trabalho posterior, Ewing ${ }^{5}$ (1968) relata que apenas $0,3 \%$ das amostras de Salmonella estudadas no mesmo Centro eram lactose positivas. Outros autores têm descrito o iøolamento de estirpes lactose positivas de Salmonella. Assim Saphra e col. ${ }^{1+}$ isolaram o sorotipo newington de fezes; Seligmann e Saphra ${ }^{15}$ isolaram o mesmo sorotipo de um caso fatal de meningite; Falkow e Baron ${ }^{7}$ relatam o isolamento do

* Da Disciplina de Microbiologia da Faculdade de Farmácia e Odontologia de Araraquara Rua Expedicionários do Brasil, 1.621 Araraquara, SP Brasil. 
FALCÃO, D. P. - Meio modificado de cultura para caracterização de Salmonella lactosepositiva. Rev. Saúde públ., S. Paulo, 10:65-73, 1976.

sorotipo typhi de fezes; Bulmash e cols. ${ }^{3}$ referem o isolamento do sorotipo tennessee também de fezes; Kunz e Ewing ${ }^{12}$ do sorotipo typhi de sangue e urina; Gonza$\mathrm{les}^{8}$ do sorotipo tennessee de um caso de septicemia, todas lactose positivas. Mais recentemente Blackbum e Ellis ${ }^{2}$ (1973), observaram que $15,6 \%$ de Salmonella isoladas de leite em pó eram lactose positivas e pertenciam aos sorotipos anatum, tennessee e newigton.

Na cidade de São Paulo, Brasil, à partir de 1971 essa variedade lactose positiva de Salmonella tem sido considerada endêmica. Pessôa ${ }^{13}$, em 1972, descreve o isolamento de 313 amostras de lactose positivas de Salmonella typhimurium, var. Copenhagem. Também em São Paulo, Almeida e Trabulsi ${ }^{1}$, relatam que, durante $o$ ano de 1973, 56\% de amostras de Salmonella isoladas de materiais clínicos diversos eram do sorotipo typhimurium, fermentadoras de lactose.

As colônias de Salmonella lactose-positivas são idênticas às colônias de $E$. coli nos meios de cultura à base de lactose, tornando impossivel distinguir colônias de Salmonella lactose-positivas das colônias de $E$. coli em tais meios de cultura.

O presente trabalho tem por objetivo desenvolver um meio de cultura isento de lactose. empregando outro carbohidrato como indicador de fermentação, a fim de que as estirpes lactose positivas e lactose negativas de Salmonella apresentem a mesma morfologia colonial, procurando desse modo evitar-se que estirpes lactose postivas de Salmonella deixem de ser identificadas por serem confundidas com aquelas de $E$. coli.

\section{MATERIAL E METODOS}

\section{Hektoen Enteric Agar Modificado}

Foi desenvolvido um meio à partir de uma modificação do meio de Hektoen Enteric Agar (King e Metzger ${ }^{10,11}$ ), retirando a lactose e introduzindo xilose e
L-lisina, baseando-se na experiência de Taylor ${ }^{17}$.

A presente fórmula foi definida depois de estudadas e testadas algumas variaçães:

L-lisina $\ldots \ldots \ldots \ldots \ldots \ldots \ldots \quad 5 \mathrm{~g}$

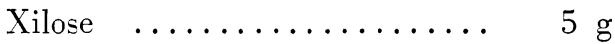

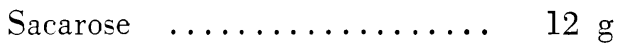

Salicina $\ldots \ldots \ldots \ldots \ldots \ldots .2 \mathrm{~g}$

Bile Salts $n .{ }^{\circ} 3 \ldots \ldots \ldots \ldots . \quad 15 \mathrm{~g}$

Cloreto de sódio ......... $5 \mathrm{~g}$

Proteose peptona ......... $12 \mathrm{~g}$

Extrato de carne ........... $3 \mathrm{~g}$

Ágar-Ágar ........................... 15 g

Água $\ldots \ldots \ldots \ldots \ldots \ldots . \ldots 100 \mathrm{ml}$

Aquecer até a ebulição. Acertar o pH a 7,5 e adicionar:

Solução de azul de bromo timol

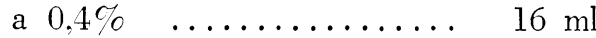
Indicador de Andrade ...... $20 \mathrm{ml}$

Ferver novamente e adicionar assepticamente $20 \mathrm{ml}$ de solução $\mathrm{A}$ e $20 \mathrm{ml}$ de solução B.

Solução A :

Desoxicolato de sódio ....... $10 \mathrm{~g}$ Água $\ldots \ldots \ldots \ldots \ldots \ldots \ldots 100 \mathrm{ml}$

Solução B:

Tiossulfato de sódio ........ $34 \mathrm{~g}$

Citrato de ferro amoniacal .... $4 \mathrm{~g}$ Água .............. $100 \mathrm{ml}$

Esterilizar as soluçôes $\mathrm{A}$ e $\mathrm{B}$ a $60^{\circ} \mathrm{C}$ por uma hora em banho maria.

O mecanismo do Meio Modificado é assim explicado:

Para Salmonella: todas as salmonelas com exceção da $S$. paratyphi $A$ e algumas amostras de $S$. typhi, S. anatum e $S$. newington, fermentam a xilose; todas descarboxilam a lisina (com exceção da $S$. para- 
FALCAO, D. P. - Meio modificado de cultura para caracterização de salmonella lactosepositiva. Rev. Sauide públ., S. Paulo, 10:65-73, 1976.

typhi A). Havendo acidificação da xilose, o pH cai. Entretanto como há descarboxilação da lisina, o $\mathrm{pH}$ reverte de ácido para alcalino, e as colônias adquirem a aparência de não fermentadoras. Aparece também cor preta no centro porque todas as salmonelas (com exceção de $S$. paratyphi $A, S$. sendai, $S$. berta e algumas de S. typhi), produzem $\mathrm{H}_{2} \mathrm{~S}$.

Para Citrobacter: esses germes fermentam a xilose, não descarboxilam a lisina e produzem $\mathrm{H}_{2} \mathrm{~S}$. Portanto suas colônias são típicas ácidas com centro preto.

Para Shigella: esses germes não fermentam a xilose, a salicina e raramente o fazem com sacarose, não descarboxilam lisina e não produzem $\mathrm{H}_{2} \mathrm{~S}$. Suas colônias são típicas não fermentadoras.

Para Coliformes: a grande maioria de $E$. coli bem como outros coliformes são xilose positivas. Também grande parte dos coliformes fermentam a sacarose e a salicina. Verificamos assim que quase todos os germes desse grupo acidificam um ou todos esses açúcares, produzindo colônias ácidas típicas. Não produzem $\mathrm{H}_{2} \mathrm{~S}$. A fim de que não haja reversão de $\mathrm{pH}$ devido aos germes lisina-positivos, adicionamos sacarose e salicina em excesso. O ácido em excesso produzido por esses açúcares, impede a reversão do $\mathrm{pH}$ daqueles coliformes lisina-positivos.

Para Proteus: essas bactérias podem ou não fermentar a xilose, salicina e sacarose, não descarboxilam a lisina, produzindo ou não $\mathrm{H}_{2} \mathrm{~S}$. Não apresentam comportamento colonial típico no Meio Modificado, como no caso das outras enterobactérias estudadas.

\section{Outros Meios Avaliados:}

Juntamente com o Meio Modificado foram avaliados outros meios usados no isolamento de enterobactérias: SS Agar, Brilliant Green Agar (B.G.A.), Hektoen Enteric Agar, todos da marca Difco e Hektoen Enteric Agar preparado no laboratório.
O trabalho foi desenvolvido em 2 fases:

Numa primeira fase as bactérias foram semeadas no Meio Modificado para verificação do comportamento e caracterização colonial. Nessa fase trabalhou-se com as seguintes bactérias:

17 amostras de Salmonella typhimurium lactose positivas.

25 amostras de Salmonella lactose negativas, dos diversos grupos sorológicos.

12 amostras de Shigella (3 S. sonnei, $6 S$. flexneri, $1 S$. boydi, 2 dysinteriae).

35 amostras de Proteus (15 P. mirabilis, $8 P$. vulgaris, $2 P$. rettgeri, $10 P$. morganii).

\section{3 amostras de Citrobacter. \\ 60 amostras de Coliformes.}

Numa segunda fase realizamos um estudo quantitativo comparativo entre o Meio Modificado e outros meios empregados para isolamento de enterobactérias. Os germes escolhidos (Salmonella lactose positiva e lactose negativa, Shigella, Proteus e Coliformes, foram diluídos seriadamente em salina a $0,85 \%\left(10^{-1}\right.$ a $\left.10^{-10}\right)$. Semeou-se $0,1 \mathrm{ml}$ de cada diluição em SS Agar, Brilliant Green Agar, Hektoen Enteric Agar, (Difco); Hektoen Enteric Agar preparado no laboratório e no Meio Modificado. Após incubação a $37^{\circ} \mathrm{C}$ durante 24 horas, foi feita a contagem do nủmero de colônias.

\section{RESULTADOS}

A descrição da morfologia colonial das diversas enterobactérias estudadas, no Meio Modificado, pode ser observada na Tabela 1.

A contagem comparativa do número de colônias, nos diferentes meios estudados, pode ser observada nas Tabelas $2,3,4$, 5 e 6. 
FALCAO, D. P. - Meio modificado de cultura para caracterização de Salmonella lactosepositiva. Rev. Saúde públ., S. Paulo, 10:65-73, 1976.

TABELA 1

Morfologia colonial de algumas enterobactérias no "Meio Modificado"

\begin{tabular}{l|l}
\hline \multicolumn{1}{c}{ Germe } & \multicolumn{1}{c}{ Caracterizaçá } \\
\hline Salmonella lactose positiva & $\begin{array}{l}\text { Colónias convexas, circulares, transparentes, } \\
\text { de tamanho médio, de cor verde com centro } \\
\text { preto. }\end{array}$ \\
\hline Salmonella lactose negativa & $\begin{array}{l}\text { Colônias convexas, circulares, transparentes, } \\
\text { de tamanho médio, de cor verde com ou sem } \\
\text { centro preto. }\end{array}$ \\
\hline Citrobacter & $\begin{array}{l}\text { Colónias altas, opacas, grandes, de cor ama- } \\
\text { relo-salmáo, com centro preto. }\end{array}$ \\
\hline Shigella & $\begin{array}{l}\text { Colónias convexas, circulares, transparentes, } \\
\text { pequenas, de cor verde. }\end{array}$ \\
\hline Coliformes & $\begin{array}{l}\text { Colônias altas, opacas, grandes, de cor ama- } \\
\text { relo-salmão. }\end{array}$ \\
\hline Proteus & $\begin{array}{l}\text { Colónias convexas, circulares, transparentes, } \\
\text { de tamanho médio, de cor verde com ou sem } \\
\text { centro preto. }\end{array}$ \\
\hline
\end{tabular}

Nota: No Melo Modificado as colôntas de Pseudomonas apresentam-se de cor verde ou marron, com bordos irregulares, são altas e grandes.

TABELA 2

Contagem do número de colônias de estirpes lactose-negativas de Salmonella nos meios de cultura estudados

\begin{tabular}{|c|c|c|c|c|c|c|}
\hline $\begin{array}{l}\text { N.o da } \\
\text { amostra }\end{array}$ & Germe & SS Agar & B.G.A. & $\begin{array}{c}\text { Meio } \\
\text { Modifi- } \\
\text { cado }\end{array}$ & $\begin{array}{c}\text { Hektoen } \\
\text { Difco }\end{array}$ & $\begin{array}{c}\text { Hektoen } \\
\text { Lab. }\end{array}$ \\
\hline 10 & s. typhimurium & $34 \times 10^{8}$ & $40 \times 10^{7}$ & $52 \times 10^{8}$ & $66 \times 10^{8}$ & $43 \times 10^{8}$ \\
\hline 48 & s. bovis morbificans & $35 \times 10^{9}$ & $30 \times 10^{8}$ & $34 \times 10^{2}$ & $37 \times 10^{9}$ & $34 \times 10^{\circ}$ \\
\hline 53 & S. typhi & $37 \times 10^{9}$ & $30 \times 10^{4}$ & $35 \times 10^{\circ}$ & $35 \times 10^{0}$ & $36 \times 10^{9}$ \\
\hline 2 & S. paratyphi $A$ & $90 \times 10^{9}$ & $37 \times 10^{5}$ & $85 \times 10^{9}$ & $97 \times 10^{9}$ & $93 \times 10^{9}$ \\
\hline 43 & S. vejle & $82 \times 10^{9}$ & $90 \times 10^{9}$ & $78 \times 10^{\circ}$ & $80 \times 10^{\circ}$ & $77 \times 10^{\circ}$ \\
\hline 81 & S. carrau & $30 \times 10^{3}$ & $88 \times 10^{\top}$ & $30 \times 10^{8}$ & $30 \times 10^{8}$ & $31 \times 10^{3}$ \\
\hline 60 & S. berta & $98 \times 10^{8}$ & $103 \times 10^{2}$ & $30 \times 10^{8}$ & $31 \times 10^{8}$ & $31 \times 10^{8}$ \\
\hline 132 & S. mississipi & $131 \times 10^{8}$ & $100 \times 10^{3}$ & $145 \times 10^{8}$ & $123 \times 10^{8}$ & $156 \times 10^{8}$ \\
\hline 70 & S. zanzibar & $43 \times 10^{10}$ & $35 \times 10^{10}$ & $42 \times 10^{10}$ & $45 \times 10^{10}$ & $41 \times 10^{10}$ \\
\hline 96 & S. meleagridis & $80 \times 10^{\circ}$ & $41 \times 10^{5}$ & $39 \times 10^{\circ}$ & $47 \times 10^{\circ}$ & $30 \times 10^{2}$ \\
\hline 90 & S. rubislaw & $41 \times 10^{\circ}$ & $58 \times 10^{7}$ & $57 \times 10^{9}$ & $46 \times 10^{\circ}$ & $31 \times 10^{\circ}$ \\
\hline 66 & S. give & $173 \times 10^{6}$ & $98 \times 10^{8}$ & $54 \times 10^{7}$ & $30 \times 10^{7}$ & $50 \times 10^{7}$ \\
\hline 78 & s. aberdeen & $57 \times 10^{9}$ & 0 & $58 \times 10^{9}$ & $50 \times 10^{\circ}$ & $78 \times 10^{\circ}$ \\
\hline
\end{tabular}


FALCAO. D. P. - Mejo modificado de cultura para caracterizaçāo de salmonella lactosepositiva. Rev. Saude plibl.. S. Paulo, 10:65-73, 1976.

\section{T A B E L A 3}

Contagem do número de colónias de estirpes positivas de Salmonella nos meios de cultura estudados

\begin{tabular}{|c|c|c|c|c|c|c|}
\hline $\begin{array}{l}\text { N.O da } \\
\text { amostra }\end{array}$ & Germe & SS Agar & B.G.A. & $\begin{array}{c}\text { Meio } \\
\text { Modifi- } \\
\text { cado }\end{array}$ & $\begin{array}{l}\text { Hektoen } \\
\text { Difco }\end{array}$ & $\begin{array}{l}\text { Hektoen } \\
\text { Lab. }\end{array}$ \\
\hline $\mathrm{H} 2 \mathrm{SMI}$ & s. typhimurium & $60 \times 10^{-}$ & $35 \times 10^{7}$ & $43 \times 10^{-}$ & $30 \times 10^{\tau}$ & $44 \times 10^{-}$ \\
\hline 1314 & S. typhimurium & $30 \times 10^{\circ}$ & $30 \times 10^{-}$ & $132 \times 10^{-}$ & $101 \times 10^{-}$ & $132 \times 10^{t}$ \\
\hline 1918 & S. typhimurium & $30 \times 10^{2}$ & $180 \times 10^{\mathrm{s}}$ & $205 \times 10^{s}$ & $209 \times 10^{8}$ & $210 \times 10^{8}$ \\
\hline 1917 & S. typhimurium & $31 \times 10^{3}$ & $150 \times 10^{8}$ & $250 \times 10^{s}$ & $261 \times 10^{3}$ & $290 \times 10^{3}$ \\
\hline 1760 & S. typhimurium & $50 \times 10^{6}$ & $182 \times 10^{8}$ & $198 \times 10^{\mathrm{s}}$ & $201 \times 10^{8}$ & $193 \times 10^{3}$ \\
\hline 1892 & S. typhimurium & $57 \times 10^{8}$ & $30 \times 10^{s}$ & $30 \times 10^{9}$ & $25 \times 10^{9}$ & $30 \times 10^{9}$ \\
\hline $18 \$ 2$ & S. typhimurium & $33 \times 10^{5}$ & $58 \times 10^{3}$ & $40 \times 10^{9}$ & $37 \times 10^{9}$ & $41 \times 10^{9}$ \\
\hline
\end{tabular}

TABELA 4

Contagem do número de colônias de Shigella nos meios de cultura estudados

\begin{tabular}{|c|c|c|c|c|c|c|}
\hline $\begin{array}{l}\text { No da } \\
\text { amostra }\end{array}$ & Germe & SS Agar & B.G.A. & $\begin{array}{l}\text { Meio } \\
\text { Modifi- } \\
\text { cado }\end{array}$ & $\begin{array}{c}\text { Hektoen } \\
\text { Difco }\end{array}$ & $\begin{array}{l}\text { Hektoen } \\
\text { Lab. }\end{array}$ \\
\hline 219 & S. sonnei & $35 \times 10^{5}$ & 0 & $36 \times 10^{s}$ & $30 \times 10^{8}$ & $44 \times 10^{8}$ \\
\hline 107 & S. sonnei & $52 \times 10^{5}$ & 0 & $35 \times 10^{8}$ & $44 \times 10^{8}$ & $106 \times 10^{8}$ \\
\hline 266 & S. sonnei & $30 \times 10^{3}$ & 0 & $157 \times 10^{s}$ & $64 \times 10^{8}$ & $148 \times 10^{8}$ \\
\hline 310 & S. flexneri & $104 \times 10^{s}$ & 0 & $222 \times 10^{8}$ & $141 \times 10^{8}$ & $224 \times 10^{8}$ \\
\hline 16 & S. flexneri & $69 \times 10^{5}$ & 0 & $50 \times 10^{9}$ & $65 \times 10^{8}$ & $59 \times 10^{8}$ \\
\hline 663 & S. flexner & $70 \times 10^{s}$ & 0 & $81 \times 10^{s}$ & $65 \times 10^{8}$ & $71 \times 10^{8}$ \\
\hline 8 & S. flexneri & $36 \times 10^{9}$ & 0 & $35 \times 10^{9}$ & $38 \times 10^{9}$ & $37 \times 10^{8}$ \\
\hline 670 & S. boydi & $106 \times 10^{9}$ & 0 & $30 \times 10^{9}$ & $30 \times 10^{9}$ & $172 \times 10^{8}$ \\
\hline 342 & S. dysinteriae & $30 \times 10^{9}$ & 0 & $36 \times 10^{9}$ & $35 \times 10^{9}$ & $34 \times 10^{9}$ \\
\hline 3 & S. dysinteriae & $40 \times 10^{9}$ & 0 & $39 \times 10^{9}$ & $41 \times 10^{9}$ & $38 \times 10^{9}$ \\
\hline
\end{tabular}


FALCÃo, D. P. - Meio modificado de cultura para caracterização de Salmonella lactosepositiva. Rev. Saúde públ., S. Paulo, 10:65-73, 1976.

TABELA 5

Contagem do número de colônias de coliformes nos meios de cultura estudados

\begin{tabular}{|c|c|c|c|c|c|c|}
\hline $\begin{array}{l}\text { N.0 da } \\
\text { amostra }\end{array}$ & Germe & SS Agar & B.G.A. & $\begin{array}{c}\text { Meio } \\
\text { Modifi- } \\
\text { cado }\end{array}$ & $\begin{array}{c}\text { Hektoen } \\
\text { Difco }\end{array}$ & $\begin{array}{c}\text { Hektoen } \\
\text { Lab. }\end{array}$ \\
\hline 667 & $E$. coli & $100 \times 10^{5}$ & 0 & $30 \times 10^{9}$ & $30 \times 10^{\circ}$ & $30 \times 10^{9}$ \\
\hline 554 & E. coli & $93 \times 10^{7}$ & 0 & $34 \times 10^{7}$ & $53 \times 10^{7}$ & $52 \times 10^{7}$ \\
\hline 459 & $E$. coli & $200 \times 10^{7}$ & $50 \times 10^{1}$ & $130 \times 10^{8}$ & $136 \times 10^{8}$ & $152 \times 10^{8}$ \\
\hline 295 & E. coli & $35 \times 10^{7}$ & 0 & $34 \times 10^{7}$ & $92 \times 10^{7}$ & $65 \times 10^{7}$ \\
\hline 694 & E. coli & $30 \times 10^{9}$ & 0 & $31 \times 10^{\ominus}$ & $30 \times 10^{9}$ & $30 \times 10^{\circ}$ \\
\hline 709 & E. coli & $190 \times 10^{3}$ & 0 & $62 \times 10^{9}$ & $135 \times 10^{9}$ & $152 \times 10^{\circ}$ \\
\hline 701 & E. coli & $150 \times 10^{4}$ & 0 & $70 \times 10^{7}$ & $42 \times 10^{8}$ & $32 \times 10^{8}$ \\
\hline 34 & E. coli & $87 \times 10^{8}$ & 0 & $32 \times 10^{8}$ & $73 \times 10^{8}$ & $148 \times 10^{8}$ \\
\hline 556 & E. coli & $75 \times 10^{4}$ & 0 & $80 \times 10^{8}$ & $126 \times 10^{8}$ & $148 \times 10^{8}$ \\
\hline 674 & Klebsiella & $84 \times 10^{8}$ & $150 \times 10^{\tau}$ & $138 \times 10^{8}$ & $102 \times 10^{8}$ & $280 \times 10^{8}$ \\
\hline
\end{tabular}

T A B E A 6

Contagem do número de colônias de Proteus nos meios de cultura estudados

\begin{tabular}{|c|c|c|c|c|c|c|}
\hline $\begin{array}{l}\text { N. }{ }^{\circ} \text { da } \\
\text { amostra }\end{array}$ & Germe & SS Agar & B.G.A. & $\begin{array}{c}\text { Meio } \\
\text { Modifi- } \\
\text { cado }\end{array}$ & $\begin{array}{l}\text { Hektoen } \\
\text { Difco }\end{array}$ & $\begin{array}{l}\text { Hektoen } \\
\text { Lab. }\end{array}$ \\
\hline 43 & P. mirabilis & $36 \times 10^{10}$ & 0 & $42 \times 10^{10}$ & $30 \times 10^{10}$ & $43 \times 10^{10}$ \\
\hline 42 & P. mirabilis & $175 \times 10^{9}$ & 0 & $228 \times 10^{9}$ & $118 \times 10^{9}$ & $130 \times 10^{\circ}$ \\
\hline 48 & P. mirabilis & $37 \times 10^{10}$ & 0 & $40 \times 10^{10}$ & $42 \times 10^{10}$ & $39 \times 10^{10}$ \\
\hline 50 & P. mirabilis & $35 \times 10^{10}$ & 0 & $39 \times 10^{10}$ & $30 \times 10^{10}$ & $30 \times 10^{10}$ \\
\hline 51 & P. mirabilis & $286 \times 10^{\circ}$ & 0 & $136 \times 10^{9}$ & $158 \times 10^{9}$ & $141 \times 10^{\circ}$ \\
\hline 26 & P. vulgaris & $290 \times 10^{9}$ & 0 & $211 \times 10^{\theta}$ & $135 \times 10^{9}$ & $181 \times 10^{\circ}$ \\
\hline 2 & P. vulgaris & $54 \times 10^{8}$ & 0 & $90 \times 10^{8}$ & $30 \times 10^{8}$ & $59 \times 10^{8}$ \\
\hline 78 & $P$. vulgaris & $32 \times 10^{10}$ & 0 & $33 \times 10^{10}$ & $35 \times 10^{10}$ & $34 \times 10^{10}$ \\
\hline 102 & P. rettgerii & $38 \times 10^{9}$ & 0 & $30 \times 10^{9}$ & $31 \times 10^{0}$ & $30 \times 10^{x}$ \\
\hline 103 & P. rettgerii & $30 \times 10^{10}$ & 0 & $31 \times 10^{10}$ & $30 \times 10^{10}$ & $30 \times 10^{10}$ \\
\hline
\end{tabular}


FALCAO, D. P. - Meio modificado de cultura para caracterizaçāo de salmonella lactosepositiva. Rev. Saúde públ., S. Paulo, 10:65-73, 1976.

\section{DISCUS A O}

Através dos resultados obtidos observamos que o Meio Modificado mostrou-se muito eficaz para o isolamento de Salmonella, atingindo o objetivo desejado, isto é, fazer com que todas as amostras de Salmonella apresentem morfologia colonial idêntica, eliminando desse modo a possibilidade de confundir-se as colônias lactose-positivas com colônias de $E$. coli. Todas as estirpes de Salmonella (lactosepositivas e lactose-negativas), apresentam colônias típicas não ácidas, com centro preto, exceto é claro, aquelas não produtoras de $\mathrm{H}_{2} \mathrm{~S}$. $\mathrm{Na}$ maioria das vezes a quantidade de $\mathrm{H}_{2} \mathrm{~S}$ é tão intensa que as colônias se mostram quase que inteiramente negras, com apenas um halo verde.

o Meio Modificado também é considerado bom para o isolamento de Citrobacter, pois suas colônias apresentam-se perfeitamente diferenciadas das de Salmonella devido à acidificação da xilose e não se confundem com as coliformes, pois o meio propicia uma perfeita evidenciação de $\mathrm{H}_{2} \mathrm{~S}$.

Shigella também apresentam colônias bem características nesse meio, isto é, não fermentadoras.

Os coliformes também apresentam colônias típicas amarelo-salmäo, diferenciando-se dos Citrobacter pela não produção de $\mathrm{H}_{2} \mathrm{~S}$.

No entretanto os germes do grupo Proteus, podem ser confundidos quer com Salmonella, quer com Shigella. Através de dados de um estudo sobre Proteus, realizado por Suassuna ${ }^{16}$, verificamos que a maioria dessas bactérias fermentam pelo menos um dos carbohidratos existentes no Meio Modificado (xilose, sacarose e salicina). Sabemos também que os Proteus não descarboxilam a lisina. Teoricamente, pois, esses germes deveriam apresentar no Meio Modificado, quase sempre morfologia colonial típica de bactérias fermentadoras. Acreditamos que esse comportamento colonial diferente do esperado, seja devido a uma alcalinização intensa do meio por processo outro que o da descarboxilação da lisina, que irá neutralizar os ácidos formados pela fermentação dos carbohidratos.

Analisando pois o Meio Modificado em relação a sua capacidade de caracterizar as colônias de enterobactérias, verificamos que os resultados foram bastante satisfatórios, a não ser em relação aos Proteus, os quais não apresentaram colônias típicas. No entretanto, todos os outros meios de cultura para isolamento de enterobactérias à base de lactose, como carbohidrato diferenciador, também apresentam essa falha, isto é, confundem as colônias de Proteus com as de Salmonella ou Shigella.

Pudemos também observar através da morfologia colonial apresentada pelas enterobactérias no Meio Modificado, que a lactose pode ser perfeitamente substituída pelo sistema indicador xilose L-lisina.

Em relação à contagem comparativa do número de colônias no Meio Modificado e nos outros meios estudados, observando-se as Tabelas $2,3,4,5$ e 6 , verifica-se que a contagem foi muito uniforme no Meio Modificado e no meio de Hektoen Enteric Agar, quer o adquirido comercialmente, quer o preparado no laboratório, para todos os germes estudados. Verificamos também que as contagens nesses meios, de um modo geral, foram superiores às apresentadas nos de Brilliant Green Agar, para as Salmonella lactose-positivas. Para as Salmonella lactose-negativas, a contagem foi ligeiramente inferior no meio de Brilliant Green Agar.

As amostras de Shigella estudadas foram totalmente inibidas no meio de Brilliant Green Agar. No meio de SS Agar as amostras de Shigella sonnei sofreram inibição, sendo que as outras espécies apresentaram contagens bastantes semelhantes às observadas nos meios modificado e de Hektoen Enteric Agar (duas variedades).

De um modo geral as amostras de $E$. coli foram inibidas no meio de Brilliant Green Agar, o mesmo não ocorrendo com a 
FALCÃO, D, P. - Meio modíficado de cultura para caracterização de Salmonella lactosepositiva. Rev. Saúde públ., S. Paulo, 10: - 1976.

amostar de Klebsiella. O meio do SS Agar mostrou-se de um modo geral mais inibitório que o meio modificado e o de Hektoen Enteric Agar para os coliformes.

Os Proteus apresentaram contagens uniformes nos meios de SS Agar, Modificado e Hektoen Enteric Agar. Foram totalmente inibidos no Brilliant Green Agar.

Após este estudo quantitativo, concluimos que o Meio Modificado, ao lado de possibilitar uma caracterização uniforme das duas estirpes de Salmonella, bem como perfeita caracterização e diferenciação colonial dos outros gêneros de enterobactérias, não foi inibitório para as amostras estudadas.
Observamos também igualdade de comportamento bacteriano no Hektoen Enteric Agar, quer o adquirido comercialmente, quer o preparado no laboratório.

Ressaltamos que esses resultados foram ohtidos com bactérias de coleção e que o Meio Modificado será testado na rotina de isolamento de enterohactérias. Apesar de havermos trabalhado apenas com bactérias de coleção, acreditamos que os resultados foram bastante satisfatórios de modo a sugerir a introdução do Meio Modificado na rotina de isolamento de enterobactérias, com referência especial à Salmonella.

FALCÃo, D. P. - [A modified culture medium for the characterization of positive lactose strains of Salmonella]. Rev. Saúde públ., S. Paulo, 10: $65-73,1976$.

SUMmaRY: A modified culture medium was developed for the purpose of isolating and characterizing the enterobacterias, giving special attention to the Salmonella strains that ferment lactose. In this "Modified Medium" the colonies of the two strains of Salmonella show a morphological similarity. This does not occur with other culture media of enterobacteria, in which the basic carbohydrate is lactose. The Modified Medium is a modification of the Enteric Agar in which the lactose was substituted by xilose and L-lisine. It was verified that there is a possibility of differentiating between the different groups of enterobacteria by using a culture medium with no lactose and using xilose L-lisina as a differentiating system. The Modified Medium was also evaluated quantitatively comparing its enriching or inhibiting power with the Hektoen Enteric Agar, Brilliant Green Agar and the SS Agar media in relation to the different groups of enterobacteria.

UNITERMS: Enterobacterias. Salmonella, positive lactose. Culture medium.

\section{REFERENCIAS BIBLIOGRAFICAS}

1. AlmEIDA, P. C. A. \& TRABULSI, L. R. - Caracteristicas culturais, bioquimicas e virulência de amostras de Salmonella typhimurim fermentadoras da lactose. Rev. Microbiol., s: $27-35,1974$

2. BLACKBURN, B. O. \& ELLIS, B. M. Lactose fermenting Salmonella from dried milk and milk-drying plants. A ppl. Microbiol, 23:672-4, 1973.
3. BULMASH, J. M.; FULTON, M. \& JIRON, $J$. - Lactose and sulfide reactions of an aberrant Salmonella strain. J. Bacteriol., $89: 259,1965$.

4. EDWARDS, P. R. \& EWING, W. H. Identification of enterobacteriaceae, 3rd ed., Minneapolis, Burgess Publishing Co., 1972. 
FALCAO, D. P. - Melo modificado de cultura para caracterização de Salmonella lactosepositiva. Rev. Saúde públ., S. Paulo, 10:65-73, 1976.

5. EWING, W. H. - Differentiation of enterobacteriaceae by biochemical reactions. Atlanta, Center for Disease Control, 1968.

6. EWING, W. H. \& BALL, M. M. - The biochemical reactions of members of the genus Salmonella. Atlanta, Center for Disease Control, 1966.

7. FALKON, S. \& BARON, L. S. - Episomic element in a strain of Salmonella typhosa. J. Bacteriol., 84:581-9, 1962.

8. GONZALES, A. B. - Lactose fermenting Salmonella. J. Bacteriol., 91:1661-2, 1966.

9. KAUFFMANN, F. - The bacteriology of enterobacteriaceae 3rd ed. Copenhagen, Munksgaard, 1966.

10. KING, S. \& METZGER, W. - A new plating medium for the isolation of enteric pathogens. I. - Hektoen enteric agar. Appl. Microbiol., 16: $577-8,1968$

11. KING, S. \& METZGER, W. - A new plating medium for the isolation of enteric pathogens. II - Comparison of Hektoen enteric agar - with SS agar and EMB agar. Appl. Microbiol., 16:579-81, 1968 .
12. KUNZ, I. J, \& EWING, W. H. - Laboratory infection with a lactose fermenting strain of $S$. typhi. J. Bacteriol., $89: 1629,1965$.

13. PESSOA, G. V. A. - Sobre a ocorrência de uma variante Salmonella typhimurium fermentadora da lactose. São Paulo, 1972. Tese - Univ. São Paulo.

14. SAPHRA, I. \& SELIGMANN, E. - Coliforms with complet Salmonella antigen, or lactose-fermenting salmonella? $J$. Bacteriol, 54:270-1, 1947.

15. SELIGMANN, E. \& SAPHRA, I. - A coliform bacterium with the complete antigen of Salmonella newington. J. Immunol., 54:275-82, 1946.

16. SUASSUNA, I. - Estudo sobre o gênero Proteus. Rlo de Janeiro, 1963. (Tese Faculdade de Ciências Médicas do Estado da Guanabara).

17. TAYLOR, W. I. - Isolation of Shigella. I - Xllose lysina agars; new media for isolation of enteric pathogens. Reg. med. Technol., 35:471-5, 1965. Recebido para publicaçno em 28/11/1975 Aprovado para publicaşio em 05/01/1976 